linkage study using two cloned DNA sequences. $J$ Med Genet 1983;20:249-51.

3 Kosambi DD. The estimation of map distances from recombination values. Ann Eugen 1944;12:172-5.

4 Rao DC, Morton NE, Lindsten J, Hultén M, Yee S. A mapping function for man. Hum Hered 1977;27:99-104.

5 Renwick JH. Progress in mapping human autosomes. Br Med Bull 1969;25:65-73.

Haemoglobin O Arab (B121 Glu-Lys) in Turkish Cypriot population

SIR,

Hb O Arab (B121 Glu-Lys) has been reported in different ethnic groups including Sudanese, Arabs, American Negroes, Bulgarians, and recently in Turkish people. ${ }^{1-7}$ It has not previously been reported in the Turkish Cypriot population.

We investigated blood samples of 1365 apparently healthy Turkish Cypriots by cellulose acetate electrophoresis. ${ }^{8}$ When an abnormal haemoglobin was identified, citrate agar electrophoresis was performed. ${ }^{9}$ Structural analysis was performed when indicated..$^{10}$

Two haemoglobin $\mathrm{O}$ Arab traits and one $\mathrm{Hb} \mathrm{O}$ Arab $\beta$-thalassaemia combination were detected in three different families. Further study of 24 subjects from these three families revealed $13 \mathrm{Hb} O \mathrm{Arab}$ traits and two $\mathrm{Hb} O \mathrm{Arab} \beta$-thalassaemia combinations. It was observed that the subjects with $\mathrm{Hb} \mathrm{O}$ Arab had negroid characteristics (negroid Turkish Cypriots have the same physical characteristics as African Negroes; they represent less than $1 \%$ of all Turkish Cypriots). We investigated a further 19 subjects with negroid characteristics, two with $\mathrm{Hb} \mathrm{S}$ trait, one with $\mathrm{Hb} \mathrm{H}$ disease, and five with $\beta$ thalassaemia trait, but no further $\mathrm{Hb} \mathrm{O}$ Arab traits were found in these subjects.

$\mathrm{Hb} \mathrm{O}$ Arab was first detected in an Arab living in Israel, then in Egypt, Aden, Bulgaria, Rumania, Hungary, among American Negroes, and recently in Turkey. ${ }^{1-7}$ It is believed to have originated in the Sudan and to have spread from there to West Africa and to many countries once occupied by or in close contact with the Ottoman Empire. ${ }^{6} 7$

When the history of the Ottoman Empire is considered the occurrence of $\mathrm{Hb} \mathrm{O}$ Arab in Cyprus is not surprising. In 1570 the Ottomans conquered Cyprus and Anatolian Turks migrated to the island. The island was ruled by the Ottomans from the 16th to the end of the 19th century and during this period many people from Sudan and Egypt emigrated to Anatolia, Syria, Lebanon, and Cyprus. ${ }^{11}$ Identification of $\mathrm{Hb} \mathrm{O}$ Arab in Turkish Cypriots may indicate an admixture of African blood in the past.
Moreover, some Turkish Cypriots show negroid physical characteristics.

We are grateful to $\mathbf{T} \mathbf{H} \mathrm{J}$ Huisman from the Medical College of Georgia, USA, for the analysis of abnormal variants.

Șükrü Cín, Nejat Akar, Ayten Arcasoy, Ayhan O Çavdar, and Seher DedeoĞlu Pediatric Haematology and Oncology Research Unit, Medical School of Ankara University, Ankara, Turkey.

References

1 Vella F, Beale D, Lehmann H. Hemoglobin O Arab in Sudanese. Nature 1966;209:308-9.

2 Kamel KA, Hoerman KC, Awny AY. Hemoglobin $\alpha_{2} \beta_{2} 121$ Lys: chemical identification in an Egyptian family. Science $1967 ; 156: 397-8$.

3 Ibrahim SA, Mustafa D. Sickle-cell haemoglobin $O$ disease in a Sudanese family. $\mathrm{Br}$ Med $J 1967 ; 3: 715-7$.

4 Milner PF, Miller C, Grey R, Seakins M, DeJong WW, Went LN. Hemoglobin O Arab in four negro families and its interaction with hemoglobin $\mathbf{S}$ and hemoglobin $\mathbf{C}$. N Engl J Med 1970;283:1417-25.

5 Kantchev KN, Tcholakov B, Baglioni C, Colombo B. Hemoglobin O Arab in Bulgaria. Nature 1965;205:187-8.

6 Lehmann H, Huntsman RG. Man's haemoglobins. Amsterdam: North Holland, 1974.

7 Prozorova-Zamani V, Özsoylu S, Aksoy M, et al. Hb E and $\mathrm{Hb} \mathrm{E}$ like variants in individuals from Turkey. Hemoglobin $1981 ; 5: 743-8$.

8 Cin S,, Akar N, Arcasoy A, Dedeoğlu S, Çavdar AO. Kibris Türk Toplumunda thalassemia, anormal hemoglobinler ve G6PD inzim eksikliği insidansi. Doğa 1983;7:21-36.

9 Schneider RG. Identification of hemoglobins and hemoglobinopathies by electrophoresis on cellulose acetate plates impregnated with citrate agar. Clin Chem 1974;20:1111-5.

10 Huisman THJ, Jonxis JHD. The hemoglobinopathies. Techniques of identification. New York: Marcel Dekker, 1977.

11 Kutay C. Turkiye. Istiklal ve Mücadeleleri Tarihi (History of Turkish nation). Istanbul: Istanbul Matbaasi, 1958.

\section{Incidence of pyloric stenosis in British Columbia over a 12 year period}

SiR,

In a recent letter, Carter and co-workers ${ }^{1}$ mentioned that the incidence of pyloric stenosis (infantile hypertrophic pyloric stenosis, IHPS) may be falling in the general population. We would like to comment on a recent study ${ }^{2}$ done in British Columbia (BC) which investigated changes and seasonal variation in the incidence of IHPS over a 12 year period.

The BC study ${ }^{2}$ was based on a cohort of 1234 livebirths with IHPS (988 males, 246 females) born 
in BC during the years 1966 to 1977 inclusive and identified from the caseload of the population based BC Health Surveillance Registry. ${ }^{3}$ For the study period, the overall incidence rates for males and females with IHPS were $4 \cdot 6$ and $1 \cdot 2$ per 1000 livebirths respectively. Annual incidence rates for males ranged from 5.9 to $3 \cdot 8 / 1000$ livebirths and those for females ranged from 1.7 to $0 \cdot 8 / 1000$ livebirths. During the 12 year survey period, there were no significant overall incidence variations with time or season. The only exception was that the 1974 male incidence rate appeared to be significantly raised $(\mathrm{p}<0.01)$, but no similar increase was noted for females.

In conclusion, over a 12 year period BC data do not show any temporal changes in the incidence of IHPS.

\section{A D SAdovnick ANd P A Baird Department of Medical Genetics, University of British Columbia, and Health Surveillance Registry, Division of Vital Statistics, Ministry of Health, Province of British Columbia, Vancouver, Canada.}

\section{References}

1 Carter CO, Hickman V, Evans K. Pyloric stenosis: children vs sibs. J Med Genet 1983; 20:155-6.

2 Walpole IR. Some epidemiological aspects of pyloric stenosis in British Columbia. Am J Med Genet 1981;10: 237-44.

3 Lowry RB, Miller JR, Scott AE, Renwick DHG. The British Columbia Registry for Handicapped Children and Adults: evolutionary changes over twenty years. Can $J$ Public Health 1975;66:322-6. 